\title{
WEED COVER UNAFFECTED AFTER CONVERTING A DAIRY FARM TO ORGANIC PRODUCTION
}

\author{
K.C. HARRINGTON, M.A. OSBORNE and P.D. KEMP \\ Institute of Natural Resources, Massey University, Palmerston North, \\ New Zealand \\ Corresponding author: K.Harrington@massey.ac.nz
}

\begin{abstract}
One half of a Massey University dairy farm was converted to an organic production system in 2001 and the other half continued to be farmed as a conventional unit. Aspects of these two systems have been compared over the subsequent years, including the weed flora measured twice a year since 2003 along set transects within each system. Overall there has been no significant increase in the weed cover of the organic pastures during the 4 years since measurements began. With both systems, pasture weediness increased mainly after new pastures were established. Although selective herbicides could be used in the conventional system to reduce this weediness, the weed content quickly decreased to tolerable levels in the organic system through grazing management. Hairy buttercup (Ranunculus sardous) and broad-leaved dock (Rumex obtusifolius) were the two dominant species in both systems, and factors that influenced which species dominated are discussed.

Keywords: organic production, dairy farms, pastures, grazing management, hairy buttercup, broad-leaved dock.
\end{abstract}

\section{INTRODUCTION}

Recently, the number of dairy farms converting to organic production systems has increased (Reider 2007). However, farmers often fear switching to an organic system because of the concern that production levels will drop considerably, and that problems will occur once it is no longer possible to use pesticides and other chemicals that are forbidden on organic farms.

To study some of the impacts of becoming organic, Massey University split one of its seasonal supply dairy farms in two in August 2001, setting up one half as an organic farm and comparing this system with the other half, which continued to be farmed conventionally (Kelly et al. 2005). The two farmlets have been studied over the past 7 years by a team of researchers including animal, soil, plant and farm management specialists.

The objective of this paper is to report on the effects on the weed flora within the dairy farm following conversion to organic production methods. The hypothesis being tested was that changing from conventional to organic farming need not cause significant increases in weed problems.

\section{MATERIALS AND METHODS}

Both farmlets are located on a Tokomaru silt loam immediately adjacent to the Massey University campus in Palmerston North. The organic unit is 20.6 ha and conventional unit is 21.3 ha. Initially both farmlets had 44 cows, but this has been modified annually depending on the seasons and pasture available, so that in the 2007/8 season, there were 50 cows $(2.35 / \mathrm{ha})$ on the conventional unit and $46(2.23 / \mathrm{ha})$ on the organic unit, with each herd being milked separately. Organic farming methods were used on the 20.6 ha block from 1 August 2001, and AgriQuality organic certification was granted on 1 August 2003. Fertiliser was applied annually based on soil test results, with the conventional 
unit receiving traditional types of fertilisers such as potassic superphosphate, with urea to boost pasture production at times of feed shortage, while the organic unit has received such materials as reactive rock phosphate, vermicast and composted chicken manure.

Ten paddocks were randomly selected from each of the units (from totals of 24 for each of the conventional and organic farms) for detailed monitoring, and a fixed transect was established in each paddock on November 2003. The weed composition in each paddock was estimated by a skilled assessor within ten fixed quadrats, each $1 \mathrm{~m}^{2}$ in size and spaced at $5 \mathrm{~m}$ intervals along the transect. This process was repeated every 6 months for 4 years using the same assessor. The transects were located each time using a tape measure extended between fixed posts located at the edges of each paddock, and each quadrat was positioned at predetermined points along this transect.

To illustrate the effects of replanting pastures on weed composition, data are presented for two resown pastures on the conventional farmlet and two from the organic farmlet, all from the 20 monitored paddocks. On the conventional farmlet, Paddock 19 was sprayed with glyphosate on 30 March 2004 and direct-drilled 2 weeks later with a perennial ryegrass/white clover mixture. The paddock was sprayed on 23 November 2004 with a mixture of $800 \mathrm{~g}$ ai/ha 2,4-D amine (Baton), $40 \mathrm{~g}$ ai/ha flumetsulam (Preside) and $500 \mathrm{ml} / 100$ litres Uptake spraying oil. Paddock 16, on the same farmlet, was sprayed with a glyphosate/tribenuron mixture on 12 March 2005, then cultivated with a mouldboard plough, power-harrowed and planted on 2 April with a perennial ryegrass/Italian ryegrass/white clover mixture. It was sprayed on 20 May 2005 with $1.5 \mathrm{~kg}$ ai/ha MCPB. The transects used before sowing were used after sowing for each of these paddocks.

On the organic farmlet, half of Paddock 24 was mouldboard ploughed in early October 2004, power-harrowed in mid-October and in early November, then sown with perennial ryegrass, white clover, chicory and narrow-leaved plantain. The other half of the paddock was mould-board ploughed in late February 2005, power-harrowed twice then sown in late March 2005 with perennial ryegrass, white clover, red clover, Balansa clover and narrow-leaved plantain. New fixed transects were needed for these two half paddocks after sowing, as only one transect had been used prior to splitting the paddock in two.

The weed species cover data from five paddocks from each farmlet that remained in pasture for the entire 4 years were compared using T-tests for overall differences at each 6-monthly sampling. Standard errors of the mean weed cover in each of four resown pastures were also calculated.

\section{RESULTS AND DISCUSSION}

Over the 4 years that the two farmlets were monitored, at no time did the five organic permanent pastures become significantly $(\mathrm{P}<0.05)$ more weedy than the five conventional pastures (Fig. 1). Indeed, by November 2007, they were very similar in overall weed cover.

This was not really surprising, as little use was made of herbicides in established pastures anyway, due to the low level of weeds present. By keeping pastures as dense and competitive as possible, and by using good rotational grazing strategies, weeds were not permitted to become a problem. Herbicides were occasionally used on the conventional farmlet to spot spray the low numbers of Scotch thistle (Cirsium vulgare) and ragwort (Senecio jacobaea) present (mainly with a triclopyr/picloram mixture), and these species were controlled on the organic farmlet by chipping of thistles and pulling of ragwort.

However, there were times when some of the organic pastures had noticeably more weeds than the conventional ones, especially November 2004 and November 2006. This was due mainly to increased cover of hairy buttercup (Ranunculus sardous) and Californian thistle (Cirsium arvense) (Fig. 1). Note that all buttercup species were grouped together for Figure 1, but there was no giant buttercup (Ranunculus acris) on the property, and the only other buttercup species was creeping buttercup (Ranunculus repens), which remained quite constant between years. 


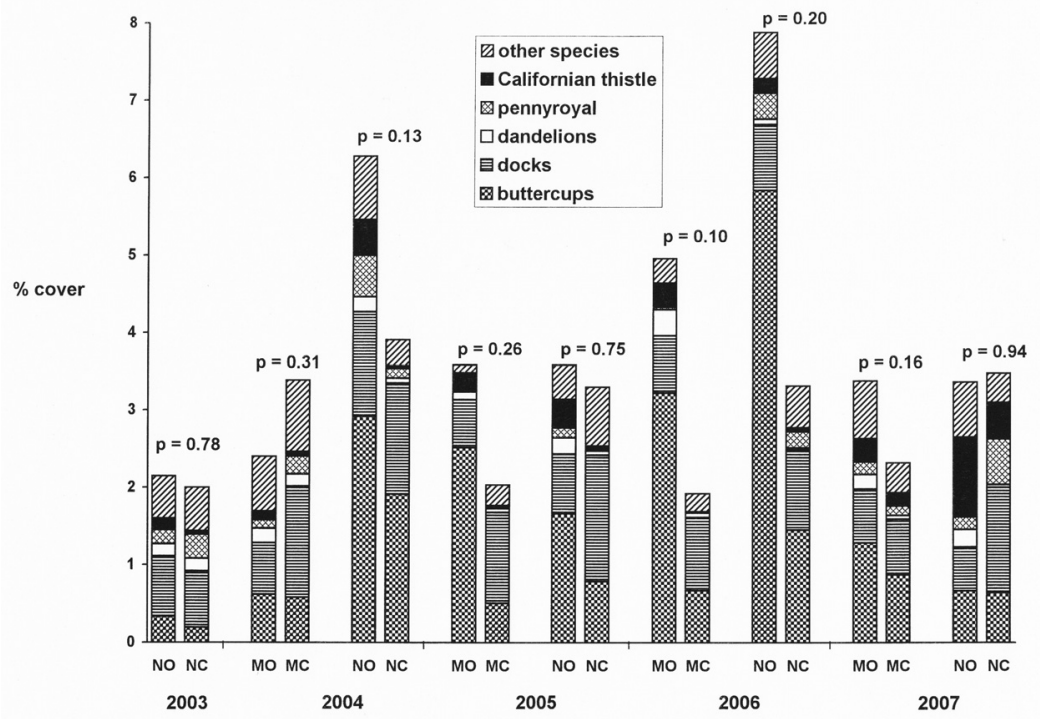

FIGURE 1: The mean estimated percentage cover of weeds in five organic $(O)$ and five conventional $(C)$ permanent pastures in November $(N)$ and May (M) from late 2003 to late 2007 . The probability that the weed cover is the same in these organic and conventional pastures at each time of monitoring is shown.

Hairy buttercup is a winter annual weed (Seefeldt et al. 2005), thus low pasture density in late autumn will assist with the establishment of populations each year. Pastures are not sprayed for buttercup on the conventional farmlet except after resowing. Differences between the conventional and organic farmlets can be explained by lower pasture covers that usually exist on the organic unit during autumn. These are caused by less supplementary feed being available for organic cows due to difficulty in obtaining sufficient suitable material, and also the application of urea that occurs each year on the conventional farmlet to boost pasture growth.

Data in Figure 1 show that the dock component of the pastures is sometimes lower on the organic pastures than the conventional pastures. The docks were mainly broadleaved dock, but there was also some clustered dock (Rumex conglomeratus) and fiddle dock (Rumex pulcher). Docks do get eaten by cows at times, but mainly when grazing pressure is increased, especially during strip-grazing over winter. The greater grazing pressure on the organic unit (due to lower inputs of supplementary feed) thus probably explains the occasional lower cover of this weed in these paddocks. Pressure has been kept on the system to show that production levels need not drop when changing to organic farming. Over the period of the trial, production has been consistently above the regional average, though not as high as the conventional unit with which it is being compared (Kelly et al. 2005).

Another trend shown in Figure 1 was a decrease over time in "dandelions" on the conventional farmlet compared with the organic pastures. This category within the graph grouped together dandelion (Taraxacum officinale), catsear (Hypochoeris radicata) and hawkbit (Leontodon taraxacoides). This trend may be a reflection of the higher nutrient input occurring on the conventional unit. Note however that dandelion can be a useful component of the sward (Harrington et al. 2006). 
Although the established pastures did not become significantly more weedy on the organic unit, the main difference between the two systems was the reduced options available to deal with weeds that grow following establishment of new pastures.

In Paddock 19 (Fig. 2a), establishment of the pasture occurred later in autumn than was desirable, and selective herbicide was not applied until November, resulting in slow establishment of pasture species and a large population of hairy buttercup, with overall weed content reaching $67 \%$ in the following spring. This highlighted that timing of operations can be important in avoiding weed problems, even in conventional systems. However, only one application of herbicide was required to bring the weed content for subsequent years below $2 \%$.
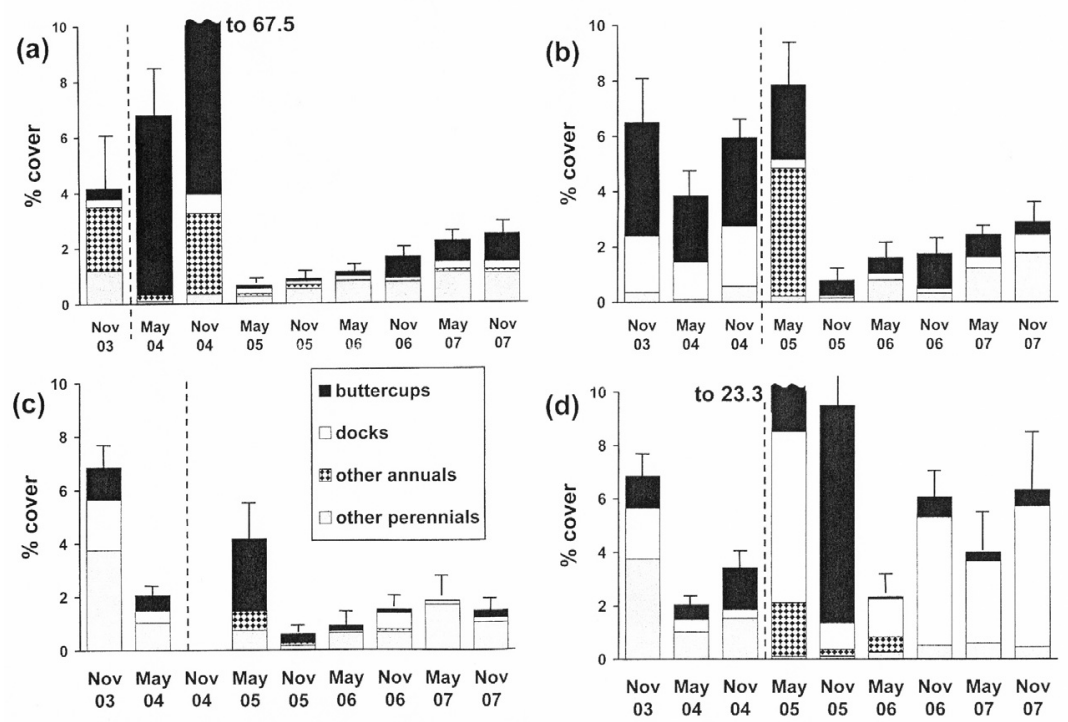

FIGURE 2: The percentage area of pasture estimated to be covered by weeds in November and May from late 2003 to late 2007 within paddocks resown (as signified by dotted lines) in: (a) May 2004 (Pdk 19-conventional); (b) April 2005 (Pdk 16-conventional); (c) November 2004 (Pdk 24-organic); and (d) March 2005 (Pdk 24-organic). Upright error bars show the standard error of means.

The other conventional pasture shown in Figure $2 b$ was established earlier in autumn resulting in rapid establishment of the sward, probably helped by the inclusion of $1 \mathrm{~kg} / \mathrm{ha}$ of Italian ryegrass and perennial ryegrass being sown at a higher rate than in the other swards studied ( $25 \mathrm{~kg} / \mathrm{ha})$. Also MCPB was applied before weeds got large, so weeds were never very noticeable in this paddock. 
For the two organic swards, selective herbicides could not be used to control the initial flush of weeds. With the spring sowing, grazing controlled upright summer annuals that established, and a fairly competitive sward was present by autumn before the main germination period for hairy buttercup (Fig. 2c). The sown chicory and plantain established well because perennial ryegrass sowing rates were kept to $12 \mathrm{~kg} / \mathrm{ha}$, and weed cover remained low in subsequent years, perhaps due to sowing in spring, or due to the combination of grasses, clovers, plantain and chicory out-competing most weed species.

As the other half of this paddock was planted in autumn, hairy buttercup established densely, making up $14.8 \%$ of the sward in late May, and total weeds were $23.3 \%$ (Fig. 2d). Once these flowered and died, they did not reinvade strongly in subsequent years, perhaps due to the strong sward of ryegrass, clover and plantain present. However, broad-leaved dock also established well in this sward, partly from regrowing root systems as glyphosate could not be used, and also from seedlings. Being perennials, these weeds did not die but continued to grow strongly in subsequent years, making up the bulk of the $6 \%$ weeds present. Broad-leaved dock has been listed as one of the main weed problems on British organic dairy farms (Turner et al. 2004).

Although the newly established organic pastures were initially weedy, the weed cover decreased to tolerable levels. Weed species such as twin cress (Coronopus didymus) in other paddocks on this farm have been brought under control by grazing with young dry stock. However, Californian thistle (Cirsium arvense) has not so easily been controlled, and some use has been made of repeated topping.

\section{CONCLUSIONS}

Weeds have not increased significantly on the organic dairy farmlet studied in this 6-year project. However, they were more difficult to manage during the establishment of the new pastures. This system was dominated by hairy buttercup and broad-leaved dock. On other farms where perennial species such as giant buttercup are present, the inability to adequately control them after pasture establishment may lead to long-lasting problems.

\section{ACKNOWLEDGEMENTS}

The authors wish to acknowledge the assistance of the many farm staff, technicians and other scientists involved with setting up and running this project. It was funded by DairyNZ (formerly Dairy Insight).

\section{REFERENCES}

Harrington KC, Thatcher AR, Kemp PD 2006. Mineral composition and nutritive value of some common pasture weeds. New Zealand Plant Protection 59: 261-265.

Kelly T, Butcher N, Harrington K, Holmes C, Horne D, Kemp P, Palmer A, Quinn A, Shadbolt N, Thatcher A 2005. Organic-conventional dairy systems trial in New Zealand: Four years' results. http://orgprints.org/4392/ [accessed 7 April 2008].

Reider R 2007. Growing organically: human networks and the quest to expand organic agriculture in New Zealand. Research report No 293, Agribusiness and Economics Research Unit, Lincoln University. 79 pp. Available at: http://hdl. handle.net/10182/133.

Seefeldt SS, Stephens JMC, Verkaaik ML, Rahman A 2005. Quantifying the impact of a weed in a perennial ryegrass - white clover pasture. Weed Science 53: 113-220.

Turner RJ, Bond W, Davies G 2004. Dock management: a review of science and farmer approaches. In: Hopkins A ed. Organic farming - Science and practice for profitable livestock and cropping. BGS Occasional Symposium No 37. British Grassland Society, Reading, UK. Pp. 53-56. 